\title{
Optimization of induced crystallization reaction in a novel process of nutrients removal coupled with phosphorus recovery from domestic wastewater
}

\author{
Haiming Zou ${ }^{1,2 *}$, Yan Wang ${ }^{1}$ \\ ${ }^{1}$ Anhui Science and Technology University, Fengyang, PR China \\ College of Resource and Environment \\ ${ }^{2}$ Ministry of Agriculture, Bengbu, PR China \\ Key Laboratory of Bio-organic Fertilizer Creation
}

*Corresponding author's e-mail: hmzou@126.com

\begin{abstract}
Keywords: phosphorus recovery, induced crystallization (IC), Hydroxyapatite (HAP), domestic wastewater, enhanced biological phosphorus removal (EBPR).

Abstract: Phosphorus removal and recovery from domestic wastewater is urgent nowadays. A novel process of nutrients removal coupled with phosphorus recovery from domestic sewage was proposed and optimization of induced crystallization reaction was performed in this study. The results showed that $92.3 \%$ of phosphorus recovery via induced Hydroxyapatite crystallization was achieved at the optimum process parameters: reaction time of $80 \mathrm{~min}$, seed crystal loads of $60 \mathrm{~g} / \mathrm{L}, \mathrm{pH}$ of $8.5, \mathrm{Ca} / \mathrm{P}$ mole ratio of 2.0 and $4.0 \mathrm{~L} / \mathrm{min}$ aeration rate when the $\mathrm{PO}_{4}^{3-} \mathrm{P}$ concentration was $10 \mathrm{mg} / \mathrm{L}$ in the influent, displaying an excellent phosphorus recovery performance. Importantly, it was found that the effect of reaction temperature on induced Hydroxyapatite crystallization was slight, thus favoring practical application of phosphorus recovery method described in this study. From these results, the proposed method of induced HAP crystallization to recover phosphorus combined with nutrients removal can be an economical and effective technology, probably favoring the water pollution control and phosphate rock recycle.
\end{abstract}

\section{Introduction}

Nitrogen $(\mathrm{N})$ and phosphorus $(\mathrm{P})$ are the two most important elements in the growth of algae $\left(\mathrm{C}_{106} \mathrm{H}_{263} \mathrm{O}_{110} \mathrm{~N}_{16} \mathrm{P}\right)$ in wastewater bodies. According to the Liebig's law of the minimum, $\mathrm{P}$ is the most limiting nutrient to algae growth in natural waters. However, surface waters usually suffer outgrowth of algae due to the excessive $\mathrm{P}$ input from effluent of wastewater treatment plants (WWTPs) or various land uses, probably leading to potential eutrophication. Therefore, there is an increasing need to develop P removal technologies for meeting the stringent discharge requirements.

Many techniques have been developed for P removal, among which enhanced biological phosphorus removal (EBPR) is one of the most widely used methods (Kamika et al. 2014, Liu et al. 2014). Denitrifying Phosphorus accumulating organisms (DPAOs) are the most important microorganisms in EBPR and its metabolic pathway is as follows: polyphosphate (polyP) hydrolysis associated with carbon sources uptake in anaerobic and anoxic polyP synthesis (Zafiriadis et al. 2013, Zhang et al. 2015), where a P-rich activated sludge is generated in the sequential anaerobic/anoxic conditions. And then, P removal could be achieved by discharging the P-rich sludge.
This may result in increasing treatment and disposal costs and loss of phosphate rocks. Yuan et al. (2012) reported a proportion of $15 \%$ or more $\mathrm{P}$ of cell dry weight in the P-rich sludge. So, it should be noted that recovering $\mathrm{P}$ from wastewater is no longer a possibility, but rather an obvious and urgent reality due to the fact that $\mathrm{P}$, differentiating from $\mathrm{N}$, is a non-renewable finite resource in the crust ( $\mathrm{Lu}$ et al. 2016, Rahaman et al. 2014, Schütte et al. 2015). Generally, $P$ in land finally flows to sea, non-easily returning to land only by catching fish. Losses of $\mathrm{P}$ from land to sea have attracted considerable attention in Europe (Grimvall et al. 2000). Consequently, there is a clear need to develop a combination process of $\mathrm{P}$ removal with $P$ recovery from wastewater to both prevent water pollution and recycle phosphate minerals.

Previous studies have found that chemical precipitation (struvite or Hydroxyapatite) is an efficient technology for $\mathrm{P}$ recovery from bulk solution generated the P-rich sludge (mentioned above) anaerobic digestion (Raj et al. 2013, Schütte et al. 2015, Xu et al. 2012). Phostrip is a typical combination process of biological nutrients removal with $P$ recovery via chemical precipitation (Lv and Yuan 2015), presenting the $\mathrm{P}$ recovery designed outside biological treatment process. Although it exhibited good P removal and recovery efficiencies, 
the disadvantages of the process are also obvious, namely, the establishment and running of sludge digestion device would cause an increase of operation cost, precipitation products could not easily be used directly in practice due to high water content, it is difficult to separate precipitation products from other solids.

For this, a novel process combining EBPR with induced crystallization (IC), EBPR-IC for short, was developed in our previous research (Zou et al. 2014a). An outstanding advantage of the EBPR-IC is that incorporating $\mathrm{P}$ recovery unit was incorporated inside EBPR system, thus greatly simplifying its design and operation. As previously mentioned, DPAOs can hydrolyze polyP by microbial enzymes in anaerobic, thus resulting in a generation of P-rich bulk solution at the end of anaerobic phase, which would provide a chance of $\mathrm{P}$ recovery. For EBPR-IC, the other advantage of using IC for P recovery is that crystallized products contain lower water content, thus favoring the practical application of it to industrial or agricultural activities. Our previous results have demonstrated that EBPR-IC had an excellent nutrients removal and $\mathrm{P}$ recovery efficiencies (Zou et al. 2014a), and P recovery greatly enhanced the biological P removal efficiency (Zou et al. 2014). Although those, we still lack a clear understanding of whether or how some environmental conditions affect the IC reaction and optimal working parameters of IC remain unclear, which may potentially limit the development of the EBPR-IC system in practice.

The main objective of this work was to focus on the influence of process parameters on IC, including reaction time, temperature, seed crystal dose, $\mathrm{pH}, \mathrm{Ca} / \mathrm{P}$ mole ratio and aeration rate in order to determine the optimum operation conditions to perform the $\mathrm{P}$ recovery.

\section{Material and methods}

\section{Experimental setup and operation procedures}

The EBPR combined with IC process (Figure 1) was carried out in a two-sludge system consisting of DPAOs sludge responsible for denitrifying simultaneous $\mathrm{N}$ and $\mathrm{P}$ removal and aerobic sludge capable of nitrification. The working volumes of anaerobic tank, aerobic tank, anoxic tank, post aeration tank were all $3.5 \mathrm{~L}$ and that of the settling tank was $4.0 \mathrm{~L}$. The IC column had a working volume of $2.5 \mathrm{~L}$ and mainly consisted of reaction zone, buffer zone and settling zone. Here, the operational procedures of EBPR-IC were briefly summarized to the following: (1) domestic wastewater flowed into anaerobic tank for anaerobic P release; (2) anaerobic supernatant was partly pumped into IC column for recovering P; (3) the rest of anaerobic supernatant together with IC supernatant flowed into aerobic tank for nitrification; (4) and then flowed into anoxic tank for anoxic $\mathrm{N}$ and $\mathrm{P}$ removal; (5) before discharging, bulk solution was aerated with oxygen in post aeration tank to enhance effluent quality. In IC column, calcite was used as a seed crystal for induced HAP crystallization in reaction zone. After settling, seed crystal associated with crystallized product again returned to reaction zone. In addition, a concentrated calcium chloride solution was used to provide $\mathrm{Ca}^{2+}$ for induced HAP crystallization.

\section{Experimental design}

In order to investigate the effect of process parameters on induced HAP crystallization in IC column, the reaction time, temperature (controlled with a heating rod), seed crystal dose, $\mathrm{pH}, \mathrm{Ca} / \mathrm{P}$ mole ratio and aeration rate were gradually increased respectively (see Table 1). During the experimental period, a synthetic wastewater containing $10 \mathrm{mg} / \mathrm{L} \mathrm{P}$ was provided by the influent.

\section{Analytical methods}

Effluent of each experimental design were regularly sampled and filtered through a $0.45 \mu \mathrm{m}$ microporous membrane filter immediately. $\mathrm{PO}_{4}^{3-}-\mathrm{P}$ was analyzed according to the standard method (APHA 2005).

\section{Results and discussion}

\section{Influence of reaction time and temperature}

The IC performance in terms of specific $\mathrm{P}$ recovery efficiencies against different reaction time and temperature

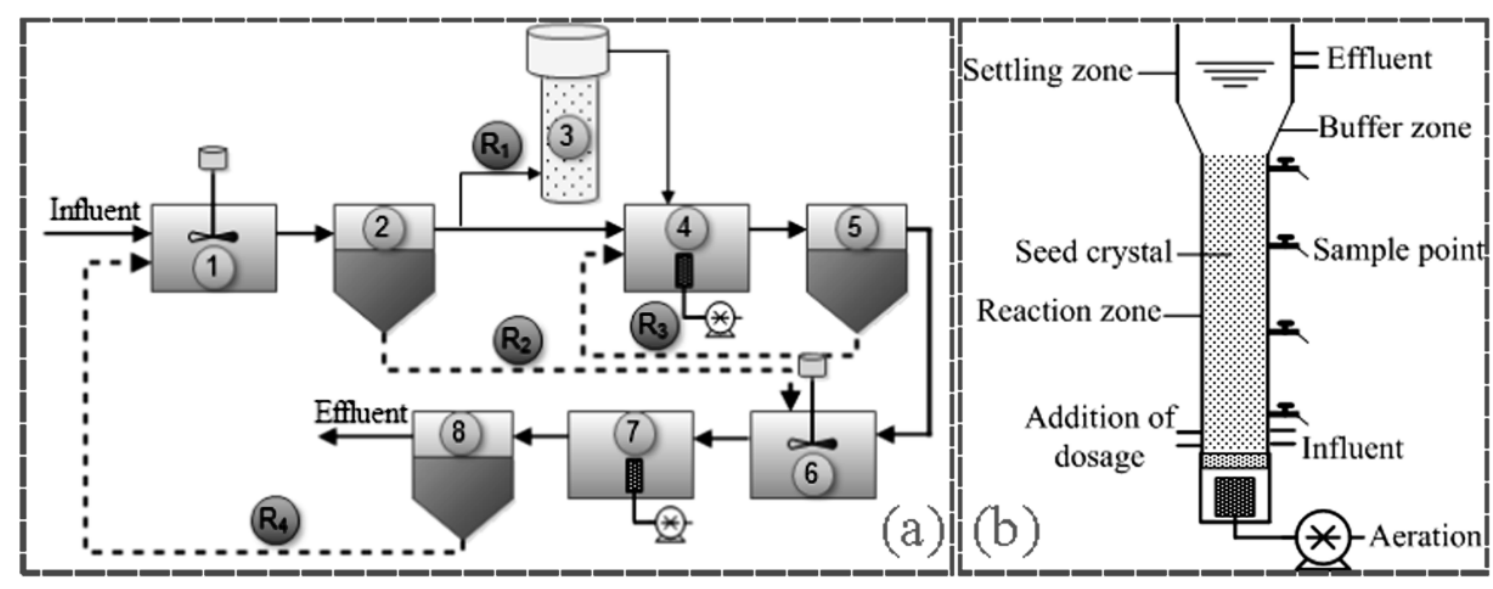

Fig. 1. Schematic diagram of EBPR combined with IC process. (a) process flowsheet of EBPR-IC, including: (1) anaerobic tank, (2) settling tank, (3) IC column, (4) aerobic tank, (5) settling tank, (6) anoxic tank, (7) post aeration tank, (8) settling tank, $\mathrm{R}_{1}$ side-stream, $R_{2}$ bypass sludge, $R_{3}$ and $R_{4}$ return sludge; (b) constructional details of IC column 
is presented in Figure 2. With the increase of reaction time, the specific $\mathrm{P}$ concentrations in the effluent decreased and the Precovery efficiencies increased correspondingly. Particularly, the $\mathrm{P}$ concentrations of effluent dropped fast, ranging from $10 \mathrm{mg} / \mathrm{L}$ to $1.74 \mathrm{mg} / \mathrm{L}$, for $70 \mathrm{~min}$ at the beginning of induced HAP crystallization reaction. And then, it declined slowly. However, influence of reaction temperature on IC was not significant compared with reaction time (Figure 2-a). Here, the IC column was exposed to reaction temperatures of $10^{\circ} \mathrm{C}$, $20^{\circ} \mathrm{C}$ and $30^{\circ} \mathrm{C}$ in three different operating stages, where the averaged $\mathrm{P}$ recovery efficiencies were $58.8 \pm 30.6 \%$, $64.4 \pm 30.3 \%$ and $67.4 \pm 29.8 \%$, indicating the small effect of reaction temperature on $\mathrm{IC}$, thus favoring the application of IC method in recovering $\mathrm{P}$ from wastewater. Meanwhile, the standard deviations from mean at three different reaction temperatures also suggest that reaction time has a strong influence on IC. Error bars in Figures 2-b and $c$ indicate one standard deviation of the averaged $\mathrm{P}$ concentration over the experimental period $(n=10$ for reaction time and $n=3$ for reaction temperature). The averaged $\mathrm{P}$ concentrations in terms of reaction time have a very large error bar (see Figure 2-c) regardless of reaction temperature, demonstrating again the obvious effect of reaction time on induced HAP crystallization.

To more quantitatively evaluate the effect of reaction time on IC, the curve fitting was conducted to analyze the relationship of $\mathrm{P}$ concentrations of effluent with reaction time. The linear and exponential regression equations are given in Figure 3. The coefficient of determination in exponential model is $\mathrm{R}^{2}=0.9992$, which is obviously higher than that in linear model $\left(\mathrm{R}^{2}=0.8524\right)$, suggesting that pseudo-first-order model is more suitable for analyzing the relationship of $\mathrm{P}$ recovery rates with reaction time compared with linear model.

\section{Influence of seed crystal dose}

The degressive $\mathrm{P}$ concentrations in the effluent were observed when additional doses of calcite (used as seed crystal here) were increased from $20 \mathrm{~g}$ to 40, 60 and $80 \mathrm{~g}$ (see Table 2). Correspondingly, the $\mathrm{P}$ recovery efficiencies were gradually elevated from $45.6 \%$ to $74.5 \%, 91.4 \%, 92.2 \%$, indicating that higher seed crystal loads resulted in faster kinetics and lower $\mathrm{P}$ content of effluent. And then it was slowly decreased with the continuously increasing calcite to $100 \mathrm{~g}$. This can be due to the fact that excess seed crystal loads in IC column could enhance the frequencies and intensities of collision among seed crystal with the increasing calcite dose. However, excess calcite loads in IC column may lead to the drop of crystalline products from surface of seed crystal. At the moment, it was found that solution turbidity of the effluent was significantly increased during the experimental period.

\section{Influence of $\mathrm{pH}$ on IC}

The $\mathrm{pH}$ value plays an important role in induced HAP crystallization since $\mathrm{pH}$ value can influence the $\mathrm{HPO}_{4}{ }^{2-} / \mathrm{H}_{2} \mathrm{PO}_{4}{ }^{-/}$ $\mathrm{PO}_{4}{ }^{3-}$ equilibrium in solution, as shown in equation (1).

$$
\mathrm{H}_{2} \mathrm{PO}_{4}^{-} \rightleftharpoons \mathrm{HPO}_{4}^{2-}+\mathrm{H}^{+} \rightleftharpoons \mathrm{PO}_{4}^{3-}+2 \mathrm{H}^{+}
$$

Table 1. Experimental design used here

\begin{tabular}{ll}
\hline Process parameters & Set value \\
\hline Reaction time $^{\mathrm{a}}$ & $0,10,20,30,40,50,60,70,80,90,100 \mathrm{~min}$ \\
Reaction temperature $^{\mathrm{a}}$ & $10,20,30^{\circ} \mathrm{C}$ \\
Seed crystal loads $^{\mathrm{b}}$ & $20,40,60,80,120,140 \mathrm{~g} / \mathrm{L}$ \\
$\mathrm{pH}^{\mathrm{c}}$ & $3,4,5,6,7,8,9,10,11,12,13 ; 7,7.5,8,8.5,9,9.5,10$ \\
$\mathrm{Ca} / \mathrm{P}$ mole ratio & $1.5,2.0,2.5,3.0,3.5,4.0$ \\
Aeration rate $^{\mathrm{e}}$ & $1.5,2,2.5,3,3.5,4,4.5,5,5.5,6,6.5,7,7.5,8,8.5,9,9.5,10,10.5,11,11.5,12,12.5,13 \mathrm{~L} / \mathrm{min}$ \\
\hline
\end{tabular}

Notes: a, $\mathrm{pH}=8.5$, seed crystal loads $=60 \mathrm{~g} / \mathrm{L}, \mathrm{Ca} / \mathrm{P}$ mole ratio $=2.5$ and aeration rate of $300 \mathrm{~L} / \mathrm{h} ; \mathrm{b}, \mathrm{pH}=8.5, \mathrm{Ca} / \mathrm{P}$ mole ratio=2.5, aeration rate $=300 \mathrm{~L} / \mathrm{h}$, reaction time $=100 \mathrm{~min}$ and reaction temperature of $20^{\circ} \mathrm{C} ; \mathrm{C}, \mathrm{Ca} / \mathrm{P}$ mole ratio $=2.5$, aeration rate $=300 \mathrm{~L} / \mathrm{h}$, reaction time $=100 \mathrm{~min}$, reaction temperature $=20^{\circ} \mathrm{C}$ and seed crystal loads of $60 \mathrm{~g} / \mathrm{L} ; \mathrm{d}, \mathrm{pH}=9$, aeration rate $=300 \mathrm{~L} / \mathrm{h}$, reaction time $=100 \mathrm{~min}$, reaction temperature $=20^{\circ} \mathrm{C}$ and seed crystal loads of $60 \mathrm{~g} / \mathrm{L} ; \mathrm{e}, \mathrm{pH}=9, \mathrm{Ca} / \mathrm{P}$ mole ratio $=2.5$, reaction time $=100 \mathrm{~min}$, reaction temperature $=20^{\circ} \mathrm{C}$ and seed crystal loads of $60 \mathrm{~g} / \mathrm{L}$.
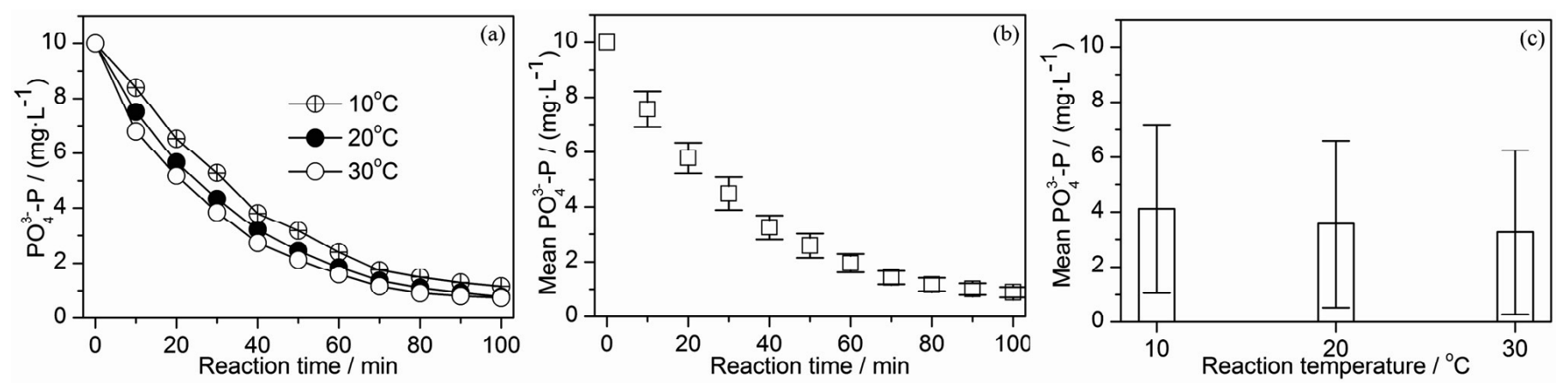

Fig. 2. Influence of reaction time and temperature on IC. (a) variations of $\mathrm{PO}_{4}{ }^{3-}-\mathrm{P}$ concentrations in the effluent with reaction time and temperature; (b) variations of mean $\mathrm{PO}_{4}{ }^{3-}-\mathrm{P}$ concentration based on reaction temperature with reaction time;

(c) variations of mean $\mathrm{PO}_{4}{ }^{3-}-\mathrm{P}$ concentration based on reaction time with reaction temperature 
Thus, it was rather crucial to understand the correlation between $\mathrm{pH}$ and $\mathrm{P}$ recovery performance of IC column. As illustrated in Figure 4, the excellent $\mathrm{P}$ recovery occurred at a wide $\mathrm{pH}$ range of above 8.0 in this study. The $\mathrm{P}$ recovery efficiencies increased rapidly with initial $\mathrm{pH}$ from 3.0 to 9.0 (Figure 4-a). This is mainly attributed to an increase in $\mathrm{PO}_{4}^{3-}$ concentration based on equation (1). And then, it slowly decreased as the $\mathrm{pH}$ further increased to 13.0. The reason could be the fact that high $\mathrm{pH}$ in solution could enhance the $\mathrm{CO}_{3}{ }^{2-}$ concentration, thus promoting the precipitation of calcium carbonate (equation (2)).

$$
\mathrm{HCO}_{3}^{-} \rightleftharpoons \mathrm{CO}_{3}^{2-}+\mathrm{H}^{+}
$$

To further investigate the $\mathrm{pH}$ influence on $\mathrm{IC}, \mathrm{P}$ recovery performances were observed at a narrow $\mathrm{pH}$ range of 7.0-13.0 (Figure 4-b), displaying that the initial $\mathrm{pH} 8.5$ was found to be favorable for induced HAP crystallization here. This is due to the following two reasons: (1) an excellent $\mathrm{P}$ recovery efficiency of $86.1 \%$ could be achieved; (2) $\mathrm{pH}$ value of 8.5 in solution could be obtained only through aeration (described below) rather than the requirement for the alkali addition, leading to saving costa.

\section{Influence of $\mathrm{Ca} / \mathrm{P}$ mole ratio on IC}

The effects of $\mathrm{Ca} / \mathrm{P}$ mole ratios were evaluated for the range of 1.50-4.00. Table 3 shows the results of the effect of added

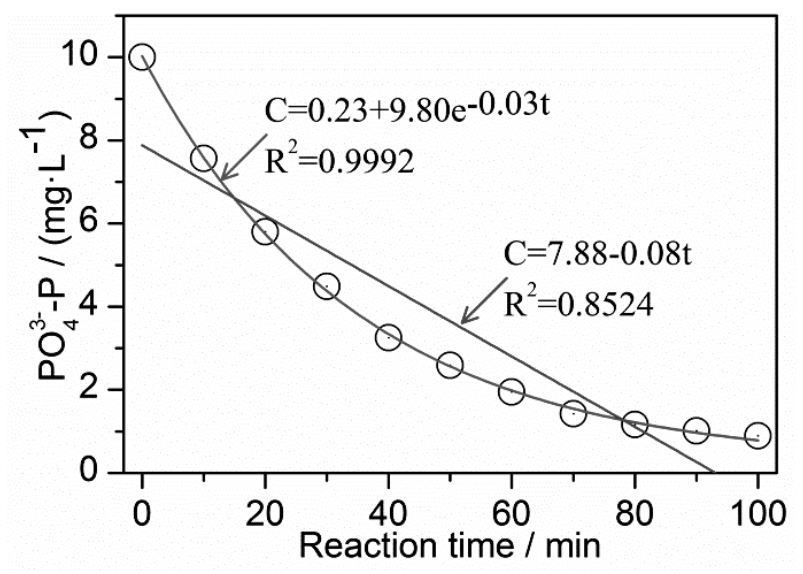

Fig. 3. Curve fitting for averaged $P$ concentration at different temperature with reaction time. $t$ : Reaction time; C: $\mathrm{P}$ concentration in the effluent

Table 2. Influence of seed crystal dose on IC

\begin{tabular}{lll}
\hline $\begin{array}{l}\text { Seed crystal } \\
\text { dose/(g) }\end{array}$ & $\begin{array}{l}\mathrm{PO}_{4}{ }^{3-}-\mathrm{P} \text { concentration } \\
\left.\text { of effluent/(mg } \cdot \mathrm{L}^{-1}\right)\end{array}$ & $\begin{array}{l}\mathrm{PO}_{4}{ }^{3-}-\mathrm{P} \text { removal } \\
\text { efficiencies/\% }\end{array}$ \\
\hline 20 & 5.44 & 45.6 \\
40 & 2.55 & 74.5 \\
60 & 0.86 & 91.4 \\
80 & 0.78 & 92.2 \\
100 & 1.31 & 86.9 \\
\hline
\end{tabular}

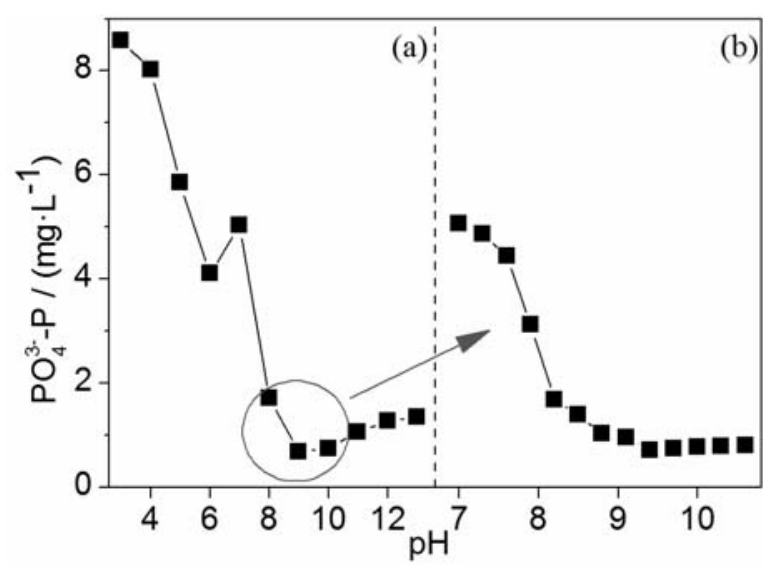

Fig. 4. Influence of $\mathrm{pH}$ on IC. (a) variations of $\mathrm{pH}$ from 3 to 13; (b) variations of $\mathrm{pH}$ from 7.0 to 10.6. 
concentrations of $\mathrm{Ca}^{2+}$ on the $\mathrm{P}$ recovery efficiencies. Lower $\mathrm{Ca} / \mathrm{P}$ mole ratios inhibited significantly $\mathrm{P}$ recovery performance via induced HAP crystallization. In fact, the limited amount of $\mathrm{Ca}^{2+}$ in solution was not favorable to HAP formation, as presented in equation (3).

$$
3 \mathrm{PO}_{4}^{3-}+5 \mathrm{Ca}^{2+}+\mathrm{OH}^{-} \rightarrow \mathrm{Ca}_{5}\left(\mathrm{PO}_{4}\right)_{3} \mathrm{OH}
$$

The $\mathrm{P}$ recovery efficiencies increased with increasing $\mathrm{Ca} / \mathrm{P}$ mole ratios. Nevertheless, at the above $\mathrm{Ca} / \mathrm{P}$ mole ratio of 2.50 , $\mathrm{P}$ recovery efficiency was almost constant regardless of the increased $\mathrm{Ca} / \mathrm{P}$ mole ratios, probably implying the insufficiency of $\mathrm{PO}_{4}^{3-}-\mathrm{P}$ amount in solution.

\section{Influence of aeration rate on IC}

The $\mathrm{P}$ recovery efficiency in IC column varied with aeration rate as shown in Figure 5. When the aeration rates ranged from $1.5 \mathrm{~L} / \mathrm{min}$ to $3.5 \mathrm{~L} / \mathrm{min}$, the final $\mathrm{P}$ recovery efficiencies were $68.9-91.6 \%$, displaying that high aeration rates were favorable to the induced HAP crystallization. This is because aeration can strip carbon dioxide from solution, thus enhancing the $\mathrm{pH}$ value of solution. In addition, aeration would greatly promote the fluidization of seed crystals, favoring the induced HAP crystallization reaction. However, excess aeration rates (above $5.5 \mathrm{~L} / \mathrm{min}$ in this study) enhance the frequencies and intensities of collision among seed crystals, thus decreasing the $P$ recovery.

\section{Conclusions}

This study showed that phosphorus recovery from domestic wastewater in a novel nutrients removal coupled with induced crystallization process was effective, exhibiting an excellent phosphorus recovery performance. Under the optimum process parameters, phosphorus recovery efficiency reached the maximum value, $92.3 \%$ when the $\mathrm{PO}_{4}^{3--} \mathrm{P}$ concentration was $10 \mathrm{mg} / \mathrm{L}$. The effect of reaction temperature on induced Hydroxyapatite crystallization was slight, thus favoring practical application of phosphorus recovery method described in this study. These results show that the proposed method of induced HAP crystallization to recover phosphorus combined with nutrients removal can be an economical and effective technology, probably favoring the water pollution control and phosphate rock recycle.

\section{Acknowledgements}

We wish to thank Dr. Dong for writing assistance and language help. This research was supported by the Natural Science Foundation of Anhui Province, China (1508085ME90) and the Special Foundation for Young Scientists of Anhui Province, China (gxyqZD2016212).

Table 3. Influence of $\mathrm{Ca} / \mathrm{P}$ mole ratio on IC

\begin{tabular}{lll}
\hline $\begin{array}{l}\mathrm{Ca} / \mathrm{P} \\
\text { mole ratio }\end{array}$ & $\begin{array}{l}\mathrm{PO}_{4}{ }^{3-}-\mathrm{P} \text { concentration } \\
\left.\text { of effluent/(mg } \mathrm{L}^{-1}\right)\end{array}$ & $\begin{array}{l}\mathrm{PO}_{4}{ }^{3-}-\mathrm{P} \text { recovery } \\
\text { efficiencies/\% }\end{array}$ \\
\hline 1.50 & 3.15 & 68.5 \\
1.75 & 2.64 & 73.6 \\
2.00 & 1.42 & 85.8 \\
2.25 & 1.06 & 89.4 \\
2.50 & 0.74 & 92.6 \\
2.75 & 0.69 & 93.1 \\
3.00 & 0.58 & 94.2 \\
3.25 & 0.61 & 93.9 \\
3.50 & 0.65 & 93.5 \\
3.75 & 0.68 & 93.2 \\
4.00 & 0.71 & 92.9 \\
\hline
\end{tabular}

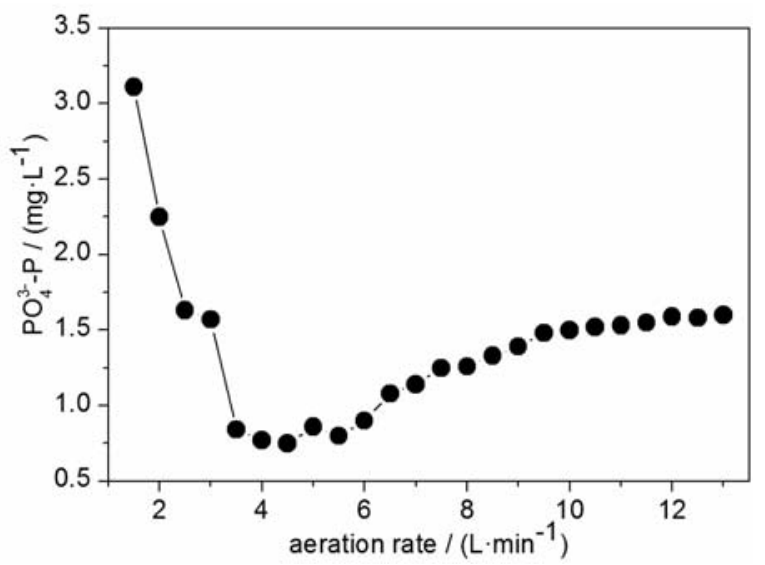

Fig. 5. Influence of aeration rate on IC 


\section{References}

APHA (2005). Standard Methods for the Examination of Water and Wastewater, 20th edn. American Public Health Association, American Water Works Association and Water Environment Federation, Washington, DC.

Grimvall, A., Stålnacke, P. \& Tonderski, A. (2000). Time scales of nutrient losses from land to sea-a European perspective, Ecological Engineering, 14, 4, pp. 363-371.

Kamika, I., Coetzee, M., Mamba, B.B., Msagati, T. \& Momba, M. (2014). The impact of microbial ecology and chemical profile on the Enhanced Biological Phosphorus Removal (EBPR) Process: A case study of northern wastewater treatment works, Johannesburg, International Journal of Environmental Research and Public Health, 11, 3, pp. 2876-2898.

Liu, Z.H., Pruden, A., Ogejo, J.A. \& Knowlton, K.F. (2014). Polyphosphate- and Glycogen-Accumulating Organisms in one EBPR system for liquid dairy manure, Water Environment Research, 86, 7, pp. 663-671.

Lu, Y., Wang, H., Kotsopoulos, T.A. \& Zeng, R.J. (2016). Advanced phosphorus recovery using a novel SBR system with granular sludge in simultaneous nitrification, denitrification and phosphorus removal process, Applied Microbiology and Biotechnology, pp. 1-8.

Lv, J. \& Yuan, L. (2015). Effects of chemical phosphate precipitation in the sidestream process on biological phosphorus removal at the anaerobic stage in an anaerobic-aerobic sequencing batch reactor, Desalination and Water Treatment, 54, 11, pp. 3011-3019.

Rahaman, M.S., Mavinic, D.S., Meikleham, A. \& Ellis, N. (2014). Modeling phosphorus removal and recovery from anaerobic digester supernatant through struvite crystallization in a fluidized bed reactor, Water Research, 51, pp. 1-10.

Raj, S.E., Banu, J.R., Kaliappan, S., Yeom, I. \& Kumar, S.A. (2013). Effects of side-stream, low temperature phosphorus recovery on the performance of anaerobic/anoxic/oxic systems integrated with sludge pretreatment, Bioresource Technology, 140, pp. 376-384.

Schütte, T., Niewersch, C., Wintgens, T. \& Yüce, S. (2015). Phosphorus recovery from sewage sludge by nanofiltration in diafiltration mode, Journal of Membrane Science, 480, pp. 74-82.

Xu, H., He, P., Gu, W., Wang, G. \& Shao, L. (2012). Recovery of phosphorus as struvite from sewage sludge ash, Journal of Environmental Sciences, 24, 8, pp. 1533-1538.

Yuan, Z., Pratt, S. \& Batstone, D.J. (2012). Phosphorus recovery from wastewater through microbial processes, Current Opinion in Biotechnology, 23, 6, pp. 878-883.

Zafiriadis, I., Ntougias, S., Kapagiannidis, A.G. \& Aivasidis, A. (2013). Metabolic behavior and enzymatic aspects of denitrifying EBPR sludge in a continuous-flow anaerobic-anoxic system, Applied Biochemistry and Biotechnology, 171, 4, pp. 939-953.

Zhang, H., Sheng, G., Fang, W., Wang, Y., Fang, C., Shao, L. \& Yu, H. (2015). Calcium effect on the metabolic pathway of phosphorus accumulating organisms in enhanced biological phosphorus removal systems, Water Research, 84, pp. 171-180.

Zou, H.M., Lu, X.W. \& Li, T. (2014). Effect of side-stream phosphorus recovery on biological phosphorus removal performance investigated by chemical and microbial analyses in a novel BNR-IC process, Water Science \& Technology, 70, 9, pp. 1441-1447. 